\begin{tabular}{|c|c|c|}
\hline UP1 & $\underset{R A}{A}$ & $\begin{array}{r}\text { JELTIM } \\
\text { Journal of English Language Teaching }\end{array}$ \\
\hline $\begin{array}{l}\text { Article received } \\
\text { Article accepted }\end{array}$ & $\begin{array}{l}\text { : March } 2^{\text {nd }}, 2019 \\
\text { April } 10^{\text {th }}, 2019\end{array}$ & $\begin{array}{r}\text { Innovations and Materials } \\
\text { Volume } 1 \text { (1), April } 2019\end{array}$ \\
\hline
\end{tabular}

\title{
Fun Meets Knowledge: English Enrichment through Camp America
}

\author{
Stella Prancisca \\ UPT Bahasa, Tanjungpura University - Indonesia \\ stellaguru123@gmail.com
}

\begin{abstract}
American Corner (Amcor) of Tanjungpura University is aware of the need to provide its EFL learners with an English community which facilitates learning within an English-speaking atmosphere, namely Camp America. Through the Camp America program, the participants obtain some crucial learning benefits, such as the opportunity for English interactive fun activities in a variety of settings, like singing, games, and seminars. Also, they experience friendly, engaging conversations with native speakers and local fluent English-speaking instructors or mentors. Camp America becomes a helpful alternative to tackle limited opportunities of EFL teachers in providing their students with English community and native speakers, through which the participants can benefit from both recreational English learning and direct engagement within an authentic English-speaking space. The space provides participants both target language community and American culture, as well as media for enhancing their integrated language skills that they can then apply into real-life practices.
\end{abstract}

Keywords

Camp America, fun activities, English learning.

\section{INTRODUCTION}

Despite years of learning English as a foreign language (EFL), Indonesian students in general are still lacking fluency in English speaking. Poor command of English is still a main factor which is lacking in the mainstream of Indonesian educational institutions, especially when it comes to EFL teaching. Conventional teaching, like the grammar translation method, remains a ominant teaching approach employed by most English teachers. Consequently, the English class' scene seems to be passive as the EFL learners do not maximally use the target language (TL) to naturally interact with other EFL learners. Since the students have no chance to simulate their English knowledge, they tend to keep the language knowledge as a hidden treasure. For example, although they actually know what to say, they have not enough courage to execute speaking, in order to interact with their peers, unless their teacher provides situational prompts that can stimulate them to do so. In this regard, there are many influential factors causing the phenomenon. These might be the teacher's role, learning time allocation, learning and teaching environment, and so forth.

Therefore, in order to overcome those problems, it is necessary to provide the students alternatives to enhance their language performance in oral English, especially speaking fluency. One of the alternatives is Camp America a program which is implemented yearly by American Corner (AMCOR) of Tanjungpura University for the students in West Kalimantan. The American Corner of Tanjungpura University is a part of the U.S. embassy's partnerships with Indonesian universities, purported to strengthen the global network and connection between the American people and Indonesia through aiding the universities where AMCOR has been established, in terms of educational and learning resources, facilitation, and human resources supports, in order to introduce a better understanding of American culture, education, and policy, as well as international affairs to people overseas in nations like Indonesia. (http://id.usembassy.gov/educationculture/american corners-indonesia/)

The main goal of this camp is to provide the participants with a fun learning atmosphere outside their regular classes. This means it focuses on fun and enjoyment in practicing English through real activities such as games, seminars, sports, and outdoor activities, and interactions with native English-speaking volunteers from America. This event is also 
expected to boost the students' interest in learning English and English fluency as they are facilitated with natural contextual English practice through vivid and fun activities conducted during the camp. Additionally, they can interact directly with both fluent Englishspeakers and native English-speakers who come from the USA. Thus, the students could have abundant opportunity to use and practice the language in the set context (e.g., having students use English to communicate during the whole of the activities, discuss problems, and work in groups or pairs).

The writing of this paper is based on observations made during the AMCOR Camp America annual events, especially the annual AMCOR Camp America 2017, which was held from Friday to Sunday, the second weekend of February. After that, the participants were asked to answer the questionnaire with open-ended questions about their impression, evaluation, and thoughts concerning the camp. In addition, personal communication was also carried out with AMCOR insiders or instructors who have been involved in each of the annual Camp America programs, from the time this program was first established until AMCOR Camp America 2017 was held. They were asked what they observed from students about their English practice during the camp.

2. LANGUAGE LEARNING PRODUCT: SPEAKING FLUENCY

Students being able to engage fluently in oral communication in English seems to be one of the main objectives of teaching and learning English as a foreign language. Without ignoring other language skills, it is obvious that language proficiency is shown through learners' ability to show their oral language competence and performance. As adopted from Chomsky's theory (1965), competence refers to the knowledge about rules of use and speaking a language, and while performance is what a learner does with the language in concrete situations (Nunan, 1988, 2012).

There is a relationship between the ability to make meaning through listening to the interlocutor's expression and the ability to execute the input through speaking. Snow (2014) articulates oral language competence as a unit that involves skills in how to say and how to listen to words to make meaning. Therefore, in order to meet the expectation, learning English as a foreign language (EFL) cannot merely rely on teaching and learning activities inside formal classrooms. Some constraints faced by EFL teachers, such as lack of time allocation, curriculum restrictions, lack of authentic texts (Shrum \& Glisan, 2009; 2016), community (native speakers), and space, might become obstacles to the learning process. Thus, it is also necessary to take the learners out of the classroom and provide a real English-speaking atmosphere and community for them through learning enrichment activities outside the classroom.

\section{AMCOR CAMP AMERICA AS AN ENGLISH LEARNING ENRICHMENT}

AMCOR Camp America provides EFL learners with an enrichment program outside school. This activity offers the participants the opportunity to gain an authentic experience of target language (TL), English speaking, and community. This 3day camp program was initiated by AMCOR of Tanjungpura University in 2013 and has continued until now. This camp event aims at providing target language community for EFL students in West Kalimantan, Indonesia. AMCOR Camp America welcomes 40 to 60 students from all levels of education, from secondary school to university and college levels in the province of West Kalimantan. Through this program, the participants may experience direct interaction with native English-speakers, who are American volunteers. The participants engage in a variety of fun activities and are required to use English to communicate with each other during the event. Based on her observations as one of the coaching instructors at the annual AMCOR Camp America, Sutiah (2017) witnessed that students participating in AMCOR Camp America enthusiastically used their English to communicate with each other, especially because English was designated as the language of instruction during the camp. The participants tried hard to use English words to have things done during camp activities, such as games and questions and answers during short seminars, even though their English was chunked or broken, or even mixed with Indonesian language (K. Sutiah, personal communication, 22 March, 2017). The activities held during the Camp America also encouraged students to try as much as they could to speak in English, shouting their emotion during the games, chitchatting with their peers and the American volunteers, and asking and answering questions in English, responding to what was instructed by the coaches 
during the activities (Y. Fransiska, personal communication, 27 March, 2017). Similarly, students noted that they had more opportunities to practice their English communication in a relaxed zone with the other campers. The requirement that all participants speak English during the camp promotes their confidence (Questionnaire camp 2017 summary).

\section{ENHANCED INTERPERSONAL SKILLS WITH OTHER MOTIVATED PARTICIPANTS WHO COME FROM DIFFERENT BACKGROUNDS.}

Accordingly, especially for English learners in West Kalimantan, Camp America, conducted by American Corner (AMCOR) is a beneficial enrichment program given to English learners, which helps both school teachers and students. In this camp, the learners experience authentic texts (Shrum \& Glisan, 2016) which are native English-speakers as resources, English as a standard medium of communication, and an American cultural environment (e.g., culture, education, foods and games related to America). Wighting, Nisbet, and Tindall in their case study about a summer English language camp in China in 2006 found that the language camp was beneficial to both students and teachers, and the camp highly motivated the participants to speak English (qtd in Aswad, 2017).

Canosa (2016) suggests that academics-based camp programs seem the ideal enterprise to advance learning opportunities. Rugasken and Haris (2009), in an annual Summer English Camp focusing on writing skills, which was held at Prince of Songkla University in Thailand, found their students exhibited an increase of word usage in their writing pieces, and the students became more confident in using words and parts of speech in their writing and making new sentences. They also affirmed that having their Thai students interact with native English speakers provided the students with many opportunities to develop their English competency. They further emphasized that their students could be independent in using English to express themselves afterwards. Likewise, Lyons-Tinsley (2014) helped by four English native speakers from her university in the USA, conducted a One-day English Camp for five schools in Surin Province in Thailand, and found that the English Language Camps showed positive involvement of participants in English. EFL teachers native to Thailand involved in the event also showed a significant increase in language clarity. In particular, Lyons-Tinsley witnessed that camp participants increased their confidence in saying English words and sounding them out (Lyons-Tinsley, 2014, p.18).

West Kalimantan, unlike other provinces in Indonesia, lacks tourists and visitors from English-speaking countries. This situation restricts the resources of native Englishspeakers' communities where the English learners may experience the real interaction in a target language atmosphere. For this reason, Camp America is worthwhile, as it is conducted to provide English learners with authentic learning resources.

\section{AMCOR CAMP AMERICA AS A LEARNING COMMUNITY}

Camp America, conducted annually by AMCOR, is open to participants from diverse educational backgrounds. This activity is purposed to provide a community to English learners that focuses on participants as the players. Using English as the standard medium language in the whole of its activities is the main rule of this activity. Hence, it covers what English classrooms in formal education institutions do not provide.

Activities held in Amcor Camp America mostly consist of fun activities such as games, character building, American education and culture sharing, movie screening, interpersonal related activities, and cooperative group work. As for cooperative group work, the participants are expected to resolve problems together, so that they need trust, reliance, and support to and from their peers. Different backgrounds are not an obstacle to achieving their united goals in accomplishing their tasks. Meanwhile, they will engage in English to communicate their ideas and accomplish tasks. Therefore, the participants have plenty of opportunities to practice their English in real life activities (the activities are not set based on a conventional teaching scenario). By the same token, a large variety of activities provided in Amcor Camp America leads the participants to actively engage in an Englishspeaking environment with both their peers and mentors (both native and non-native English speakers). In this manner, Richards (2015) suggests, "Effective teachers use different strategies to develop a sense of community among their learners, including using groupbased activities, by addressing common student interests and concerns" (p.120). 


\section{CONCLUSION}

Camp America, which is held annually by the American Corner (AMCOR) of Tanjungpura University, can be worth considering by EFL school teachers in West Kalimantan. We can learn from several benefits resulting from AMCOR Camp America annual events. In addition to all observations made so far, this is particularly true as summarized from the notes made by AMCOR Camp America 2017 participants through a questionnaire given to them at the end of the activity.

Firstly, the participants would benefit from both recreation and English knowledge where they can directly engage in a real English-speaking space, applying their knowledge to interact with their peers and instructors. In other words, they are learning English in an atmosphere that is fun, entertaining, and not scary, as well as working on an English language knowledge coaching team. Especially at AMCOR Camp America, instructors provide more games, benefits, sports, workshops, cooking demonstrations, and several variants of outdoor activities.

Secondly, participants may make more new friends and experience interesting learning situations. The participants also get more opportunities to practice their English with their peers and native English-speakers in a relaxed zone with their camp friends. Given that each participant is asked to speak in English during the camp, it also promotes their confidence.

Thirdly, through the games and problem-solving team-work activities, participants can develop critical thinking skills and reason through discussion activities. Besides using English to negotiate, participants can benefit from interpersonal related activities that can develop and improve both soft skills and leadership skills.

Finally, Camp America provides a great exposure to American information and global culture that broadens participants' knowledge about relationships with Americans, education, cuisine, geography, and so forth. Also, anxietyfree learning activities held during this event offer the learners not only fun activities, but also real experiences with target language and culture.

Nevertheless, in conducting Camp America, active collaboration among parties such as schools, parents, and American Corner as the facilitator is salient. Hence, a savvy planning is important so that this activity may result in beneficial effects to both participants' English improvement and soft-skills development.

\section{REFERENCES}

Aswad, M. (2017). The Effectiveness of English Camp: A Model in Learning English as the Second Language. Retrieved on 20 March, 2018 from https://www.researchgate.net/publication

Canosa, A.A .(2016). What Works in Education: Are summer programs effective in improving learning and educational outcomes in students? retrieved on 24 March, 2018 from http://www.ivalua.cat; http://www.fbofill.cat

Lyons-Tinsley, M. A. (2014). Conducting one day English camps in Thailand utilizing phonetics.

Nunan, D. (2012). Learner-centered English language education: The selected works of David Nunan. New York: Routledge.

Nunan, D. (1988) The Learner-Centred Curriculum. Cambridge University Press.

Wighting M.J., Deanna L. Nisbet, Tindal E. R. (2006). A Descriptive Case: Study Exploring a Summer English Language Camp Experience in China. retrieved on April 182016 from www.asian-efl-journal.com/pta_feb_06,

Snow, P. (January 01, 2014). Oral Language Competence and the Transition to School: SocioEconomic and Behavioural Factors That Influence Academic and Social Success. International Journal on School Disaffection, 11, 1, 3-24.

Richards, J. C. (2015). Key issues in language teaching. Cambridge: Cambridge University Press. Cambridge: Cambridge University Press.

Richards, J. C., \& Rodgers, T. S. (2014). Approaches and methods in language teaching.

Rugasken, Kris \& Harris, Jacqueline. (2009). English camp: A language Immersion program in Thailand. The Learning Assistance Review (TLAR), 14(2), 43-51.

Shrum, J. L., \& Glisan, E. W. (2016). Teacher's handbook: Contextualized language instruction. 
